\author{
E-ISSN: 2469-6501 \\ VOL: 7, ISSUE: 11 \\ November/2021 \\ DOI: http://dx.doi.org/10.33642/ijbass.v7n11p5 \\ (c) (i) \\ https://creativecommons.org/licenses/by/4.0/
}

\title{
Exploring Ethnic and Gender Equity Enrollment and Achievement Patterns in High School CTE Career Pathways in Mississippi
}

\author{
Dustin D. Finch \\ Research and Curriculum Unit \\ Mississippi State University \\ USA \\ Sean Owen, Ph.D.* \\ Research and Curriculum Unit \\ Mississippi State University \\ Email: sean.owen@ rcu.msstate.edu \\ USA \\ Cliff Thames \\ Research and Curriculum Unit \\ Mississippi State University \\ USA \\ Ben Alexander \\ Research and Curriculum Unit \\ Mississippi State University \\ USA
}

\section{ABSTRACT}

This study, a post hoc observational one, attempted to understand how to continue promoting equitable opportunities in career and technical education (CTE) for the state of Mississippi. We explored the enrollment patterns of Mississippi secondary CTE students by career cluster and career pathways associated with STEM careers over the last five years. Additionally, the enrollment patterns were compared to statewide enrollment patterns by gender and ethnicity. Also, we examined the proficiency results of students on the statewide CTE assessment by gender and ethnicity. Our secondary CTE student enrollment results are like previous reports of underrepresentation of nontraditional students in STEM-related career fields. Additionally, similar results were found when looking at the statewide CTE assessment data. However, there is an indication that CTE and non-CTE leaders effectively recruit underrepresented populations to STEM-related career pathways in the state of Mississippi, but more work is needed to allow access to all students.

\section{Keywords: Career and Technical Education, STEM, Equity, Assessment, Recruitment, Gender, Ethnicity}

\section{Introduction}

Equality in education has long been a focus of concern in the United States. Since the days of school segregation, there have been studies, articles, and ongoing debates about inequalities that existed in the American system. In the early days of the civil rights movement, cases like Brown v Board of Education called into question the great schism that existed among resources for minority students in the segregated school system. These disparities at first were the result of systematic efforts to curtail or deny access to various groups based on the racial biases that had long been entrenched in American society. As progress occurred (at least superficially) in terms of resources, the nature of these battles gradually evolved. Soon the goal of addressing inequalities become one more about ensuring equity so that diverse groups of students had specifically what they needed to achieve equal outcomes as their peers (Shankar-Brown, 2015). Even as these disparities have been addressed, there likely remain inherent issues of inequality and equity in the educational system due to the nature of how the education system was originally envisioned. Santos et al. (2020) claim the system was not designed to create outcomes around equity or equality; rather, the education system was designed to specifically foster methods that met the overall goal of creating workforces that fulfilled business and industry needs.

Although these problems of inequity in regular academic subjects have been the primary focus of advocates and activists for years, lesser-known disparities, such as those in career and technical education (CTE), have been (and continue to be) areas of concern.

Early examples of these concerns can be seen in the writings of 19th-century educational advocate John Dewey. Among some of his most pointed criticisms, Dewey took note of glaring disparities in the early vocational educational system nearly 100 years ago. He believed these early methods for vocational education reinforced inequality by placing some students on paths for more prestigious leadership and higher- 


\title{
International Journal of Business and Applied Social Science (IJBASS)
}

\author{
E-ISSN: 2469-6501 \\ VOL: 7, ISSUE: 11 \\ November/2021 \\ DOI: http://dx.doi.org/10.33642/ijbass.v7n11p5 \\ https://creativecommons.org/licenses/by/4.0/
}

paying careers at the expense of their lower socioeconomic peers (DeFalco, 2016).

Dewey might view today's educational landscape as one that has made some advancements toward a system that has more equity for students, but he could also likely easily point out continued discrepancies between policies and desired outcomes. While this more recent focus on historically marginalized students has been welcomed as a potential opportunity to address these concerns, there remain some potential roadblocks to understanding and addressing these issues. The federal government's leadership role in examining and addressing these issues of concern in an organized manner is one of these issues. Since the federal government has not intentionally addressed some of these issues, problem-solving has chiefly fallen to the states. The lack of federal intervention results in the development of remedies originating in the individual states. Because these state responses vary widely in both effort and solutions, truly equitable outcomes are limited (Duff \& Wohlstetter, 2019). There is a clear need to better understand possible disparities by specifically examining certain state-level data.

\section{Theoretical Framework}

The growth in career fields like science, technology, engineering, and mathematics (STEM) has presented problems in the labor market in the United States (U.S.). The biggest problem is having an inadequate number of educated workers to fill these roles (Carnevale et al., 2010; Carnevale et al., 2013; Curnow \& Calderon; 2021; Fletcher, 2012). One report states that $65 \%$ of the future jobs available in the U.S. labor market will require some postsecondary education experience by 2020 , and will continue to grow beyond (Carnevale et al., 2013). Therefore, there has been a recent push to better educate students in K-12 education to accommodate this lack of workers in these fields. Subsequently, there has been a gradual reform of the United States education system over the past 20 years to educate students focusing on CTE and postsecondary education.

Before this reform occurred, educators tracked students into one of two pathway choices during high school. The two pathway choices were a college preparatory curriculum or a vocational and job training curriculum (Dougherty, 2016, Fletcher, 2012; Hamilton et al., 2015). These two pathways led to issues that included placing students based on social constructs (e.g., students' gender, students' income status, students' race, and students with disabilities) that were potentially biased and may have suppressed enrollment in both these pathways (Fletcher, 2012; Hamilton et al., 2015; Hess, 2010). The intention to place students in these pathways was not nefarious; however, because of educators' use of this strategy, gaps were created in specific career pathways. For example, educators often find the most glaring disparities in STEM career pathways. As of 2017, women only represented $35 \%$ of participants in postsecondary STEM-related degree programs worldwide (Chavatzia, 2017).
As a result of this apparent gender inequity, policymakers began to develop policies to address this disparity and others in STEM pathways to get more students involved in these careers.

Legislatures began reforming the educational system from the typical one of two pathway choices for high school students to address present inequities in the workforce. Initially, a curriculum in high school for vocational and job training, educators believed this type of curriculum was best for the students who are more interested in entering the workforce after high school (Advance CTE, 2018). Typically, educators perceived this curriculum as less rigorous because they unintentionally associated it with low prestige and lowwage occupations (Fletcher, 2012; Hamilton et al., 2015; Rosen \& Molina, 2019). Due to this perception of vocational and job training, some pathways have reinforced the social disparities that researchers see in some career pathways (Fletcher, 2012; Hess, 2010; Landers, 2019). For example, Hess (2010) reports that more African American students participate in vocational and job training curricula than White students. Due to this higher participation rate and the negative association of this pathway, one could falsely assume that African American students do not have the same academic expectations as White students. As a result, African American students may be hindered from gaining the appropriate skills for the current labor market.

The growing gender and racial inequities discussed thus far prompted legislators to enact the Carl D. Perkins Career and Technical Education Act of 2006 (Perkins IV). The goal was to solve any problems that could exacerbate these disparities among students' gender, race, socioeconomic status, and those with disabilities. Also, legislators enacted this due to the U.S. shift in providing a more rigorous education in coursework that focuses on academic and career/technical content, encompassing both secondary and postsecondary elements (Dougherty, 2016). Plasman et al. (2020) found that STEM-related CTE courses offer one route for low-income students to reach the middle class. The education provided is more rigorous than past vocational curricula and allows students to develop skills for the current U.S. labor market. In addition, many CTE pathways include opportunities for students to receive dual credit or dual enrollment from a postsecondary institution, leading to a possible certificate or degree from the institution. The belief is that having these CTE programs will help resolve these disparities that educators see in career pathways like STEM professions (Hamilton et al., 2015). High school educators can then provide more academically challenging coursework and prepare students for more training beyond high school (Dougherty, 2016; Fletcher, 2012). The overall goal of the reform provided by Perkins IV was to better educate the students for the U.S. workforce and eliminate some of the inequities present in career pathways.

Perkins IV allowed states to fund CTE programs to better educate and prepare students for success in the 


\title{
International Journal of Business and Applied Social Science (IJBASS)
}

\author{
E-ISSN: 2469-6501 \\ VOL: 7, ISSUE: 11 \\ November/2021 \\ DOI: http://dx.doi.org/10.33642/ijbass.v7n11p5 \\ https://creativecommons.org/licenses/by/4.0/
}

workforce; however, equity in career pathways has continued to be a problem. Hamilton et al. (2015) investigated the participation patterns of historically underrepresented students in Illinois high school CTE courses in STEM fields. They specifically looked at the 2012-2013 school year from all school districts for CTE enrollment and compared their data to the national data for the 2011-2012 school year. Their data indicated more male participation (64\%) than female participation (35.8\%) in the STEM career clusters. In addition, there was a disproportion of male to female participation in almost all STEM career clusters; however, the data indicated that there was more female participation in the Health Sciences career cluster. Also, the proportion of male to female participation in non-STEM career clusters was reversed, with more females participating in these career clusters than male participation. As far as racial disparities, the data in STEM career clusters demonstrated an overrepresentation of White students in all career clusters. The data reported in Hamilton et al.'s study is more than eight years old, but CTE legislation and equity improvements are known to be a slow change (Kim et al., 2021); therefore, it is plausible that some of these inequities within STEM-related career clusters and other CTE clusters, although improving, are ongoing in other states beyond Illinois.

Every Student Succeeds Act (ESSA, 2015) was enacted to ensure that all students in the U.S. are held to a high academic standard and that educators, families, students, and communities are receiving information through statewide assessments on students' progress toward achieving these standards. In addition, the ESSA further advances equity for the learning opportunities required to develop skills in the 21st-century labor market (Cook-Harvey et al., 2016). The predecessor to ESSA, the No Child Left Behind Act of 2006 (NCLB, 2002), was intended to advance equity in traditional education, but the NCLB legislation neglected to address equity in CTE as well; therefore, Fletcher and Zirkle (2009) concluded that equity in CTE was left behind. Furthermore, the ESSA addresses this lack of focus on CTE by the NCLB and includes language that defines CTE as a component of a wellrounded education (Kim et al., 2021). In addition to the ESSA attempting to address equity in CTE, Perkins V (Perry, 2019) further builds on CTE ideals. One core indicator performance requirement in Perkins V is that all states must report on CTE participation rates and report data based on federally defined subgroups (Advance CTE, 2019). With these two pieces of legislation, the United States can further promote a more equitably skilled labor workforce.

These disparities remain a hindrance to more significant workforce issues impacting the United States (Leu $\&$ Arbeit, 2020). A lack of a qualified skill-based workforce in many areas is a concern and impediment to progress not only for gender equity but also for economic stability and growth. The majority of the U.S. population graduates high school now; however, not enough students graduate with the proper credentials required by specific employment opportunities that provide a livable-wage job (AIR, 2021). In addition, populations like students of color and lower SES represent a large and growing proportion of the U.S. population, and there is still a problem with keeping these populations enrolled and attaining postsecondary education (AIR, 2021). The problem is concerning because these populations are growing and will be the future labor workforce that the U.S. relies on to fulfill future jobs that require some postsecondary education.

The overarching goal of U.S. legislators is to cultivate an educated labor workforce so that all citizens have an equitable opportunity to participate in future jobs. As researchers in the state of Mississippi, we are interested in understanding how we can continue promoting equitable CTE opportunities for the state. Therefore, our study addresses the following research questions:

1.What are Mississippi students' CTE enrollment patterns, by gender, in both STEM and non-STEM career cluster areas?

2. What are Mississippi students' CTE enrollment patterns, by racelethnicity, in both STEM and nonSTEM career cluster areas?

3.What are Mississippi students' CTE statewide assessment proficiency patterns, by gender, in both STEM and non-STEM career cluster areas?

4.What are Mississippi students' CTE statewide assessment proficiency patterns, by racelethnicity, in both STEM and non-STEM career cluster areas?

In addition to understanding these patterns in Mississippi, there is also a critical goal to understand why students select specific CTE clusters. Social cognitive career theory (SCCT; Lent et al., 1994; Lent \& Brown, 2019) uses Bandura's (1986) triadic reciprocal causation framework with the emphasis being that career and educational development are shaped by contextual, personal, and behavioral factors (e.g., self-efficacy, social supports, goal setting). Additionally, SCCT was formed to understand better how certain aspects of persons (e.g., gender, culture, SES) may make particular career and learning experiences more or less available to individuals. The original SSCT work consisted of models focused on interest development, choice-making, and performance and persistence in educational and vocational domains (Lent et al., 1994). Although it is not the authors' goal to extend or apply SCCT, the framework is believed to be helpful when looking at the CTE enrollment patterns for gender and race and assessment of proficiency in CTE clusters in the state of Mississippi, with the goal being to give recommendations and future directions that will help all Mississippi students access an equitable educational opportunity.

\section{Methodology}

As previously discussed, it is not only a statewide but national movement toward providing more equitable opportunities to secondary students in STEM-related CTE pathways. The Research and Curriculum is the organization in 


\author{
E-ISSN: 2469-6501 \\ VOL: 7, ISSUE: 11 \\ November/2021 \\ DOI: http://dx.doi.org/10.33642/ijbass.v7n11p5 \\ (c) (†) \\ https://creativecommons.org/licenses/by/4.0/
}

the state of Mississippi responsible for helping the Mississippi Department of Education provide quality CTE experiences in public school districts as well as conduct educational research around CTE to continuously improve overall program quality. In this study, the authors used a post hoc observational research design using existing statewide secondary CTE assessment data captured during the period from 2015 to the present. This type of research is designed to explore what is currently occurring without any treatment. It is not intended to examine cause-and-effect relationships but to inform future research that is more causal or inferential in research design (Leedy \& Omrod, 2018).

\section{Population and Method of Data Collection}

The Research and Curriculum Unit (RCU) requested and obtained data from the Mississippi Department of Education containing secondary enrollment numbers for all students in CTE programs for the 2015-2021 school years. The population of this study was 132,476 students who were enrolled in secondary CTE pathways. In Mississippi, 15 of the 16 national Career Cluster areas were represented, as well as 58 distinct career pathways (Advance CTE, 2021). Seven of these 15 career clusters and 21 of 58 career pathways are STEM cluster areas.

\section{Method of Analysis}

The researchers disaggregated the dataset to analyze the research questions. For this study, the researchers were interested in identifying patterns in the enrollment of Mississippi high school CTE students in both STEM and nonSTEM fields to determine if certain trends existed by gender and race/ethnicity. Researchers gathered data for this study using career cluster and pathways' program of study enrollments by gender and race/ethnicity (separating STEM and non-STEM cluster areas). Data emerging from the research instruments were processed using the Statistical Package for Social Sciences software (SPSS 28.0) for relevant and adequate statistical analysis to generate the required statistical evidence (IBM Corp.,2021). The descriptive analysis used in this study included means and percentages. CTE enrollment patterns and statewide assessment proficiencies were also compared to statewide enrollment demographics and national science assessment proficiency patterns, respectively.

RESULTS AND DISCUSSION

\section{Results}

The presentation of the research results focuses on the research questions of the study: (1) what are Mississippi students' CTE enrollment patterns, by gender, in both STEM and non-STEM career cluster areas? (2) what are Mississippi students' CTE enrollment patterns, by race/ethnicity, in both STEM and non-STEM career cluster areas? (3) what are Mississippi students' CTE statewide assessment proficiency patterns, by gender, in both STEM and non-STEM career cluster areas? and (4) what are Mississippi students' CTE statewide assessment proficiency patterns, by race/ethnicity, in both STEM and non-STEM career cluster areas? For context, the researchers collected the high school enrollment data from the Mississippi Department of Education for the 2020-2021 school year. This data, shown in Table 1, allows the researchers to draw comparisons between enrollment patterns of CTE and non-CTE high school students.

Table 1. Mississippi High School Student Enrollment, by grade, gender, and ethnicity

\begin{tabular}{llllllll}
\hline Grade Level & Black (\%) & White (\%) & Hispanic (\%) & Asian (\%) & Other (\%) & Male (\%) & Female (\%) \\
\hline $9^{\text {th }}-12^{\text {th }}$ & $47.72 \%$ & $43.13 \%$ & $4.39 \%$ & $1.15 \%$ & $3.61 \%$ & $51.00 \%$ & $49.00 \%$
\end{tabular}

Source: MDE secondary CTE enrollment data, 2020-2021 (Mississippi Department of Education, 2021)

Statistical evidence from Table 2 indicates that a females than males in STEM-related CTE clusters. This higher percentage of males enrolled in Agriculture Food and difference is largely due to the large enrollment of females in Natural Resources, Arts, Audio-Video Technology, and the Health Science career cluster. Using the U.S. Department Communications, Information Technology, Manufacturing, of Education (2021) Perkins V 4S1: Non-traditional Program and STEM career pathways. A higher percentage of females Concentration Core Indicator of Performance definition $(25 \%$ enrolled in the STEM-related career pathways in the Health or less participation) of a nontraditional occupation to CTE Science career cluster. When comparing the secondary CTE enrollment for gender equity, the Information Technology, and enrollment with the state enrollment, there are $17.32 \%$ more Manufacturing career clusters were below the threshold.

Table 2. Mississippi HS student enrollment in STEM-related CTE clusters, by gender

\begin{tabular}{lllll}
\hline Career Cluster & Male $(\boldsymbol{n})$ & Female $(\boldsymbol{n})$ & Male $(\boldsymbol{\%})$ & Female (\%) \\
\hline Agriculture, Food, and Natural Resources & 11,505 & 7,242 & $61.4 \%$ & $38.6 \%$ \\
Arts, Audio-Video Technology, and Communications & 2,200 & 1,510 & $59.3 \%$ & $40.7 \%$ \\
Health Science & 3,442 & 21,984 & $13.5 \%$ & $86.5 \%$ \\
Information Technology & 235 & 77 & $75.3 \%$ & $24.7 \%$ \\
Manufacturing & 153 & 12 & $92.7 \%$ & $7.3 \%$ \\
Science, Technology, Engineering, and Mathematics & 7,253 & 2,866 & $71.7 \%$ & $28.3 \%$ \\
\hline Summary Data & $\mathbf{2 4 , 7 8 8}$ & $\mathbf{3 3 , 6 9 1}$ & $\mathbf{4 2 . 3 9 \%}$ & $\mathbf{5 7 . 6 1 \%}$ \\
\hline
\end{tabular}




\author{
E-ISSN: 2469-6501 \\ VOL: 7, ISSUE: 11 \\ November/2021 \\ DOI: http://dx.doi.org/10.33642/ijbass.v7n11p5 \\ (c) (†) \\ https://creativecommons.org/licenses/by/4.0/
}

The statistics in Table 3 show that the same pattern of The non-STEM CTE student enrollment is closer to the overall enrollment for males and females remained the same in the high school enrollment in the state (Mississippi Department of career clusters that were present in Table 2 and Table 3. It is Education, 2021). The Architecture and Construction career interesting to note that the patterns of enrollment by gender in cluster did not meet the threshold for the Perkins V 4S1: Noncareer clusters mimic the stereotypical female- or male- traditional Program Concentration Core Indicator of dominated roles in certain career sectors (Blau et al., 2013). Performance (United States Department of Education, 2021).

Table 3. Mississippi HS student enrollment in non-STEM CTE clusters, by gender

\begin{tabular}{|c|c|c|c|c|}
\hline Career Cluster & Male (n) & Female (n) & Male $(\%)$ & Female $(\%)$ \\
\hline Agriculture, Food, and Natural Resources & 6,190 & 2,135 & $74.4 \%$ & $25.6 \%$ \\
\hline Architecture and Construction & 6,624 & 1,371 & $82.9 \%$ & $17.1 \%$ \\
\hline Business Management and Administration & 3,233 & 6,070 & $34.8 \%$ & $65.2 \%$ \\
\hline Education and Training & 992 & 6,624 & $13.0 \%$ & $87.0 \%$ \\
\hline Finance & 49 & 114 & $30.1 \%$ & $69.9 \%$ \\
\hline Health Science & 54 & 234 & $18.8 \%$ & $81.2 \%$ \\
\hline Hospitality and Tourism & 2,394 & 5,546 & $30.2 \%$ & $69.8 \%$ \\
\hline Human Services & 388 & 6,574 & $5.6 \%$ & $94.4 \%$ \\
\hline Law, Public Safety, Corrections, and Security & 2,465 & 2,431 & $50.3 \%$ & $49.7 \%$ \\
\hline Manufacturing & 5,531 & 575 & $90.6 \%$ & $9.4 \%$ \\
\hline Marketing & 1,052 & 2,017 & $34.3 \%$ & $65.7 \%$ \\
\hline Transportation, Distribution, and Logistics & 10,227 & 1,107 & $90.2 \%$ & $9.8 \%$ \\
\hline Summary Data & 39,199 & 34,798 & $52.97 \%$ & $47.03 \%$ \\
\hline
\end{tabular}

Source: MDE secondary CTE enrollment data, 2015-2021

Globally, there was an equitable distribution of $(n=25,426)$. Except for the Manufacturing career cluster, all African American students and white students in STEM CTE STEM-related career clusters met the Perkins V 4S1: Nonclusters in Table 4. The reader may notice there is a disparity traditional Program Concentration Core Indicator of in most of the clusters apart from the Health Science career Performance (United States Department of Education, 2021). cluster due to the larger statewide enrollment of students

Table 4. Mississippi HS student enrollment in STEM-related CTE clusters, by ethnicity

\begin{tabular}{|c|c|c|c|c|}
\hline Career Cluster & White (\%) & Black $(\%)$ & Hispanic (\%) & Other $(\%)$ \\
\hline Agriculture, Food, and Natural Resources & $65.8 \%$ & $30.3 \%$ & $3.5 \%$ & $0.4 \%$ \\
\hline Arts, Audio-Video Technology, and Communications & $43.0 \%$ & $54.1 \%$ & $2.5 \%$ & $0.4 \%$ \\
\hline Health Science & $49.5 \%$ & $46.4 \%$ & $2.6 \%$ & $1.5 \%$ \\
\hline Information Technology & $63.9 \%$ & $30.3 \%$ & $3.5 \%$ & $2.3 \%$ \\
\hline Manufacturing & $78.7 \%$ & $14.0 \%$ & $6.7 \%$ & $0.6 \%$ \\
\hline Science, Technology, Engineering, and Mathematics & $53.5 \%$ & $40.0 \%$ & $4.3 \%$ & $2.2 \%$ \\
\hline Summary Data & $55.3 \%$ & $40.4 \%$ & $3.1 \%$ & $1.2 \%$ \\
\hline
\end{tabular}

Source: MDE secondary CTE enrollment data, 2015-2021

For non-STEM CTE cluster enrollments as shown in non-STEM CTE clusters meet the Perkins V 4S1: NonTable 5, Agriculture Food and Natural Resources (20.4\%), traditional Program Concentration Core Indicator of Manufacturing (38.5\%), and the Transportation, Distribution, Performance (United States Department of Education, 2021) and Logistics $(45.1 \%)$ career clusters were the only clusters for student enrollments by ethnicity except the Agriculture that did not contain a majority-minority student enrollment. All Food and Natural Resources career cluster (20.4\%). 
VOL: 7, ISSUE: 11

November/202 1

DOI: http://dx.doi.org/10.33642/ijbass.v7n11p5

Table 5. Mississippi HS student enrollment in non-STEM CTE clusters, by ethnicity

\begin{tabular}{lllll}
\hline Career Cluster & White (\%) & Black (\%) & Hispanic (\%) & Other (\%) \\
\hline Agriculture, Food, and Natural Resources & $77.6 \%$ & $20.4 \%$ & $1.7 \%$ & $0.3 \%$ \\
Architecture and Construction & $43.7 \%$ & $52.1 \%$ & $3.7 \%$ & $0.5 \%$ \\
Business Management and Administration & $38.6 \%$ & $58.1 \%$ & $2.4 \%$ & $0.9 \%$ \\
Education and Training & $46.4 \%$ & $50.7 \%$ & $2.3 \%$ & $0.6 \%$ \\
Finance & $28.9 \%$ & $69.3 \%$ & $1.8 \%$ & $0 \%$ \\
Health Science & $45.5 \%$ & $50.0 \%$ & $3.5 \%$ & $1.0 \%$ \\
Hospitality and Tourism & $36.8 \%$ & $59.5 \%$ & $2.7 \%$ & $1.0 \%$ \\
Human Services & $29.5 \%$ & $67.1 \%$ & $2.4 \%$ & $1.0 \%$ \\
Law, Public Safety, Corrections, and Security & $40.5 \%$ & $55.2 \%$ & $3.4 \%$ & $0.9 \%$ \\
Manufacturing & $58.5 \%$ & $38.5 \%$ & $2.6 \%$ & $0.4 \%$ \\
Marketing & $38.7 \%$ & $57.4 \%$ & $3.1 \%$ & $0.8 \%$ \\
Transportation, Distribution, and Logistics & $50.3 \%$ & $45.1 \%$ & $3.7 \%$ & $0.9 \%$ \\
\hline Summary Data & $\mathbf{4 7 . 0 \%}$ & $\mathbf{4 9 . 4 \%}$ & $\mathbf{3 . 0 \%}$ & $\mathbf{1 . 0 \%}$ \\
\hline
\end{tabular}

Source: MDE secondary CTE enrollment data, 2015-2021

For STEM career cluster enrollment as shown in Table non-STEM CTE clusters meet the Perkins V 4S1: Non5, Agriculture, Food, and Natural Resources (20.4\%), traditional Program Concentration Core Indicator of Manufacturing (38.5\%), and the Transportation, Distribution, Performance (United States Department of Education, 2021) and Logistics $(45.1 \%)$ career clusters were the only clusters for student enrollment by ethnicity.

that did not contain a majority-minority student enrollment. All

Table 6. Mississippi HS student enrollment in STEM CTE clusters, by ethnicity

\begin{tabular}{lllll}
\hline Career Cluster & White (\%) & Black (\%) & Hispanic (\%) & Other (\%) \\
\hline Agriculture, Food, and Natural Resources & $65.8 \%$ & $30.3 \%$ & $3.4 \%$ & $0.4 \%$ \\
Arts, Audio-Video Technology, and Communications & $43.0 \%$ & $54.1 \%$ & $2.5 \%$ & $0.5 \%$ \\
Health Science & $49.5 \%$ & $46.4 \%$ & $2.6 \%$ & $1.5 \%$ \\
Information Technology & $63.9 \%$ & $30.3 \%$ & $3.5 \%$ & $2.3 \%$ \\
Manufacturing & $78.7 \%$ & $14.0 \%$ & $6.7 \%$ & $0.6 \%$ \\
Science, Technology, Engineering, and Mathematics & $53.5 \%$ & $40.0 \%$ & $4.3 \%$ & $2.2 \%$ \\
\hline Summary Data & $\mathbf{5 5 . 3 \%}$ & $\mathbf{4 0 . 4 \%}$ & $\mathbf{3 . 1 \%}$ & $\mathbf{1 . 2 \%}$
\end{tabular}

Source: MDE secondary CTE enrollment data, 2015-2021

For non-STEM career cluster enrolment's shown in Manufacturing career cluster was the only non-STEM career Table 6, Agriculture, Food, and Natural Resources (30.3\%), cluster to meet the Perkins V 4S1: Non-traditional Program Information Technology (30.3\%), and the Manufacturing Concentration Core Indicator of Performance (United States $(14.0 \%)$ career clusters were the only clusters that did not Department of Education, 2021) for student enrollment by contain a majority-minority student enrollment. The ethnicity. 


\title{
Figure 1. STEM CTE Students Scoring Proficient or Greater on Statewide Assessment, by gender
}

\author{
- Male $\square$ Female
}

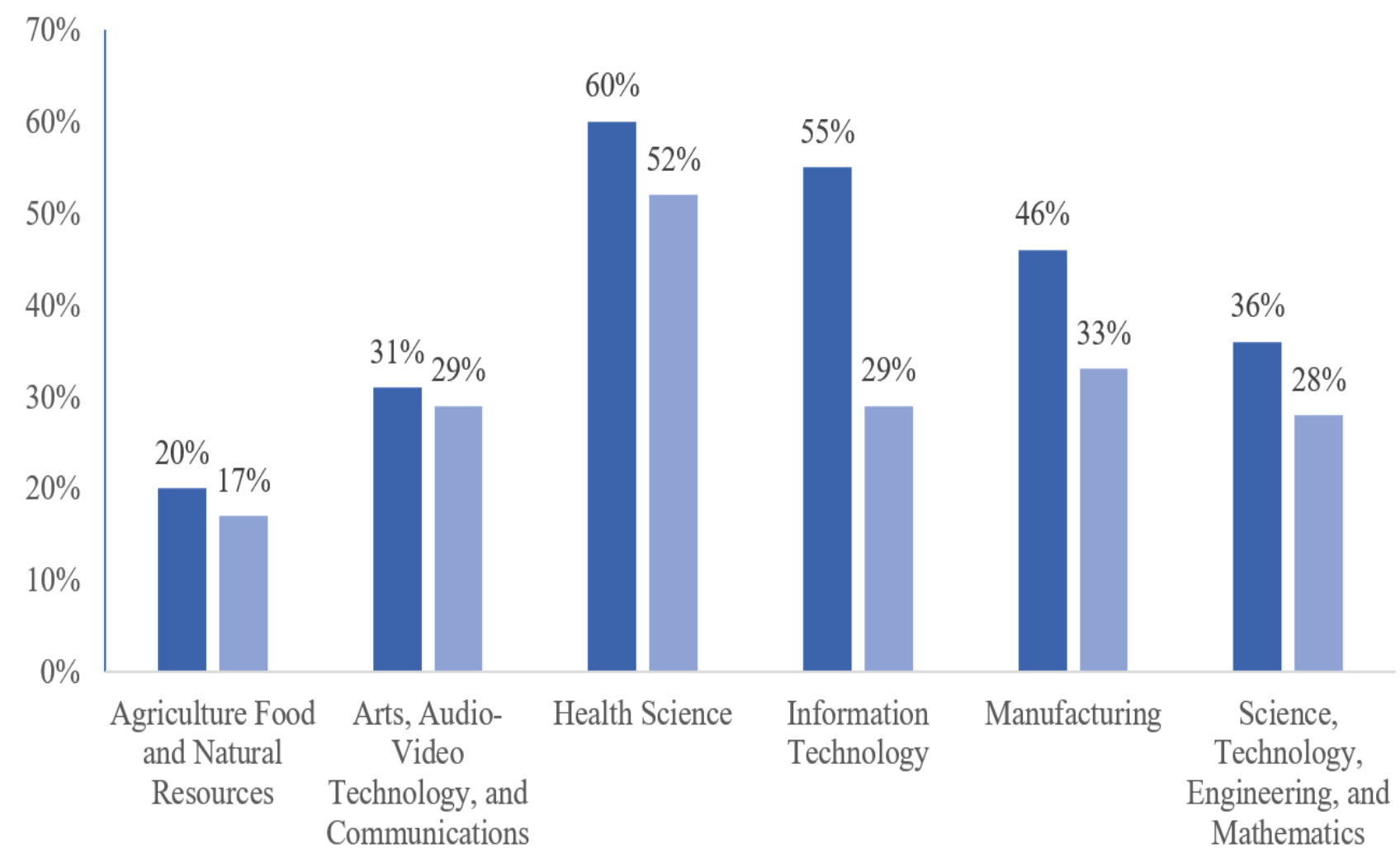

Source: MS-CPAS Assessment Data, 2015-2021

The graph displays, by STEM-related career cluster, what percentage of students by gender scored proficient on the MS-CPAS (Mississippi's state-level end of the year assessment for CTE). As Figure 1 shows, males scored proficient or higher on the statewide assessment for every career cluster grouping of courses. These results mimic the results displayed in a National Center for Education Statistics report (2017) that showed that males scored proficient or higher than females on the National Assessment of Educational Progress administered to students in 4th grade, 8th grade, and 12 th grade.
In Figure 2, statistics were calculated for students enrolled in non-STEM-related career clusters who scored proficient or higher on the MS-CPAS by gender. Males scored proficient or higher on the statewide assessment for every career cluster grouping of courses. These results were also consistent with a report that showed that the summary of National Assessment of Educational Progress results for students in the 4th grade, 8th grade, and 12th grades where males scored proficient or higher than females (National Center for Education Statistics, 2017). 


\section{Figure 2. non-STEM Students Scoring Proficient or Greater on Statewide Assessment, by gender}

\section{-Female -Male}

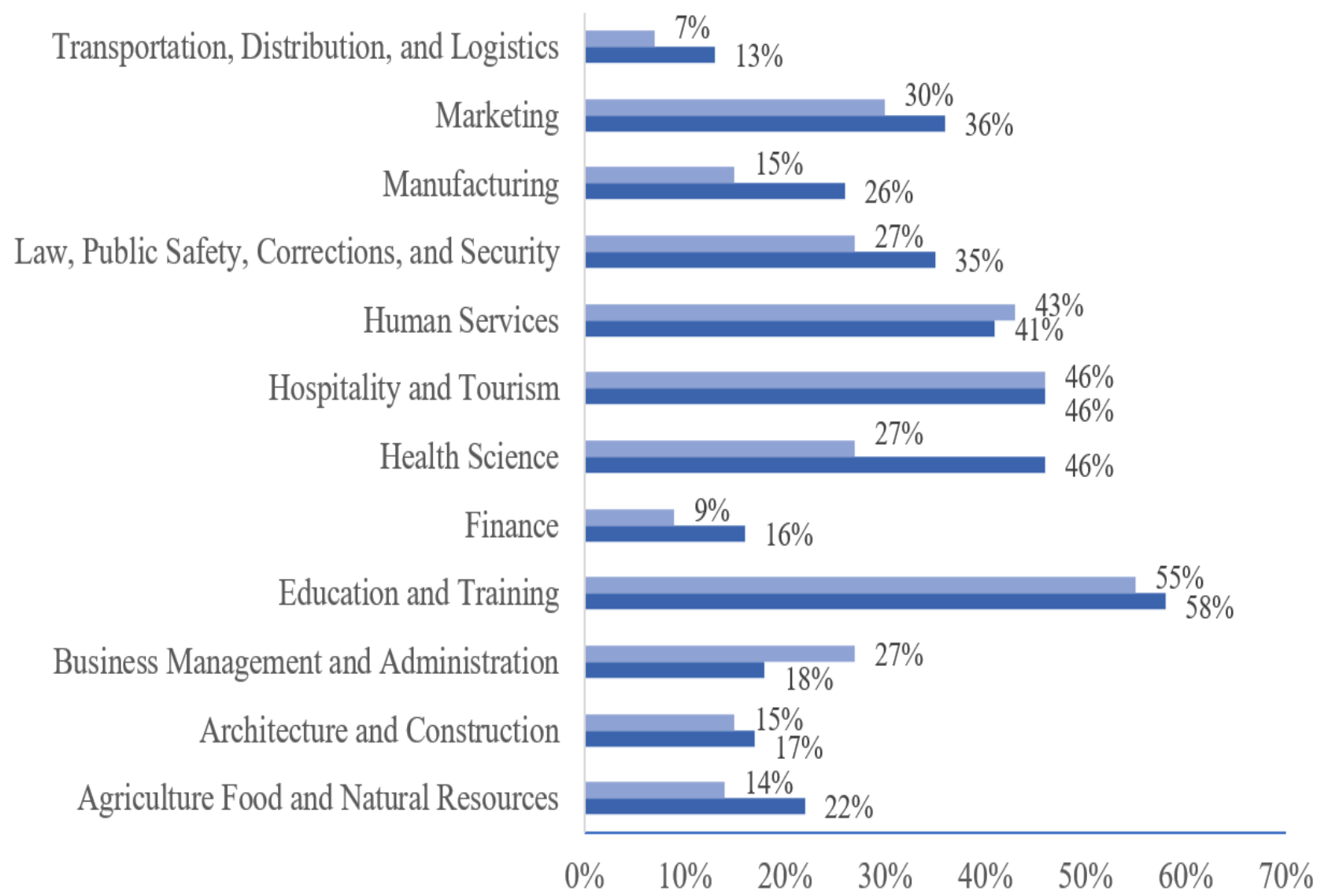

Source: MS-CPAS Assessment Data, 2015-2021

Non-traditional students who enrolled in STEM- assessments at each grade level it is administered (National related career clusters had lower proficiency rates on the MS- Center for Education Statistics, 2017). Students enrolled in the CPAS assessment for each career cluster. These results were Arts, Audio-Video Technology, and Communications had the analogous to recent National Assessment of Educational least percentage difference (16\%) between white students and Progress results where minority students had a lower African American students as compared to other career cluster percentage of proficiency for all levels of the science NAEP differences on the CTE statewide assessments. 
Figure 3. STEM CTE Students Scoring Proficient or Greater on Statewide Assessment, by ethnicity

घhite $\square$ Black $\square$ Hispanic

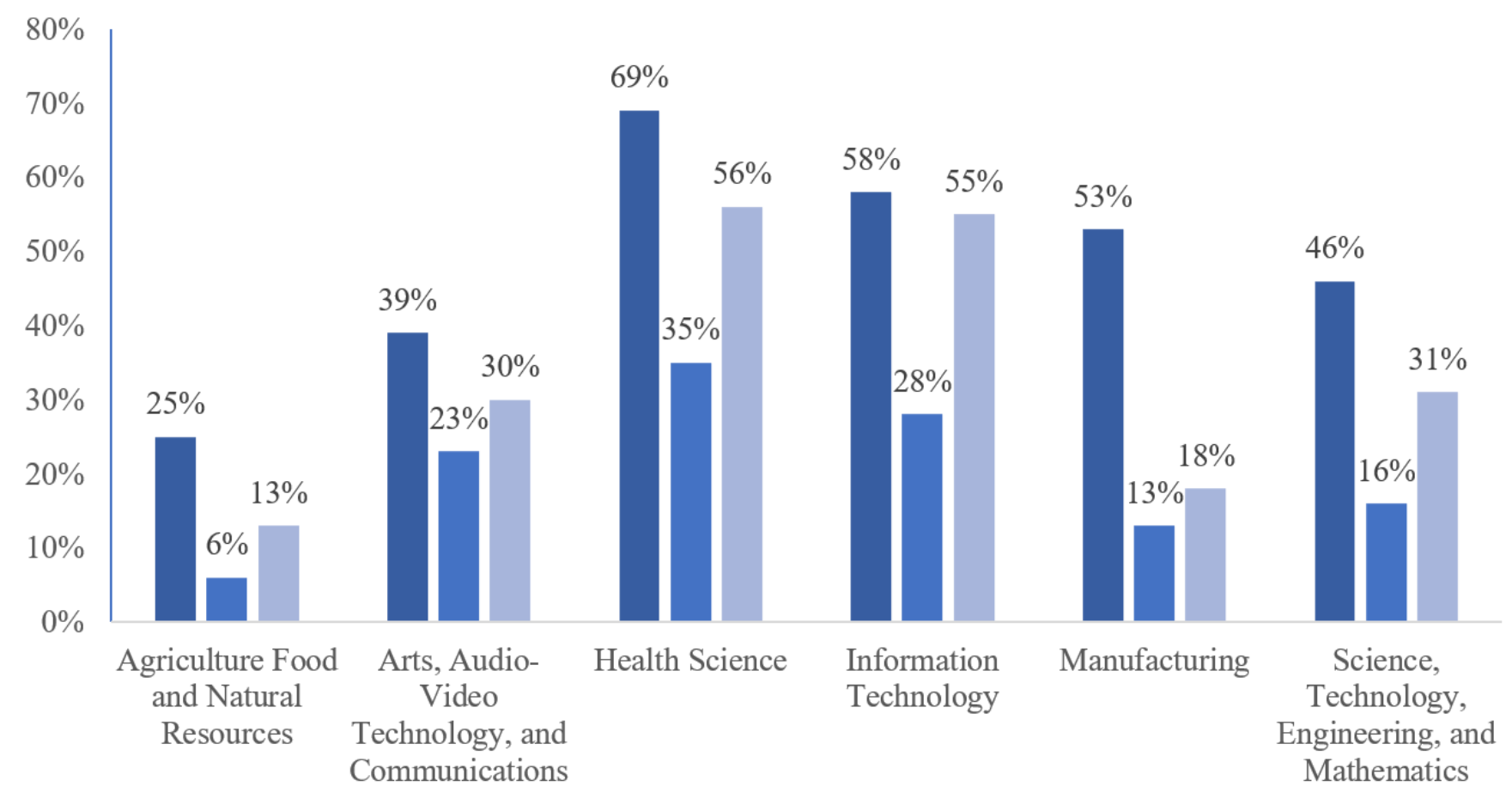

Source: MS-CPAS Assessment Data, 2015-2021

The proficiency patterns in statewide CTE assessment results for students enrolled in non-STEM-related career clusters were like students enrolled in STEM-related career clusters. Students enrolled in the Finance career pathway had the least percentage difference (14\%) between white students and African American students as compared to other career average percentage difference between traditional students and non-traditional students for all non-STEM-related career clusters was $25.08 \%$ as compared to the average percentage difference for STEM-related career clusters was $28.17 \%$. The statewide assessment proficiency results are summarized in Figures 3 and 4. 


\author{
E-ISSN: 2469-6501 \\ VOL: 7, ISSUE: 11 \\ November/2021 \\ DOI: http://dx.doi.org/10.33642/ijbass.v7n11p5 \\ (c) $($ ) \\ https://creativecommons.org/licenses/by/4.0/
}

\title{
Figure 4. non-STEM Students Scoring Proficient or Greater on Statewide Assessment, by ethnicity
}

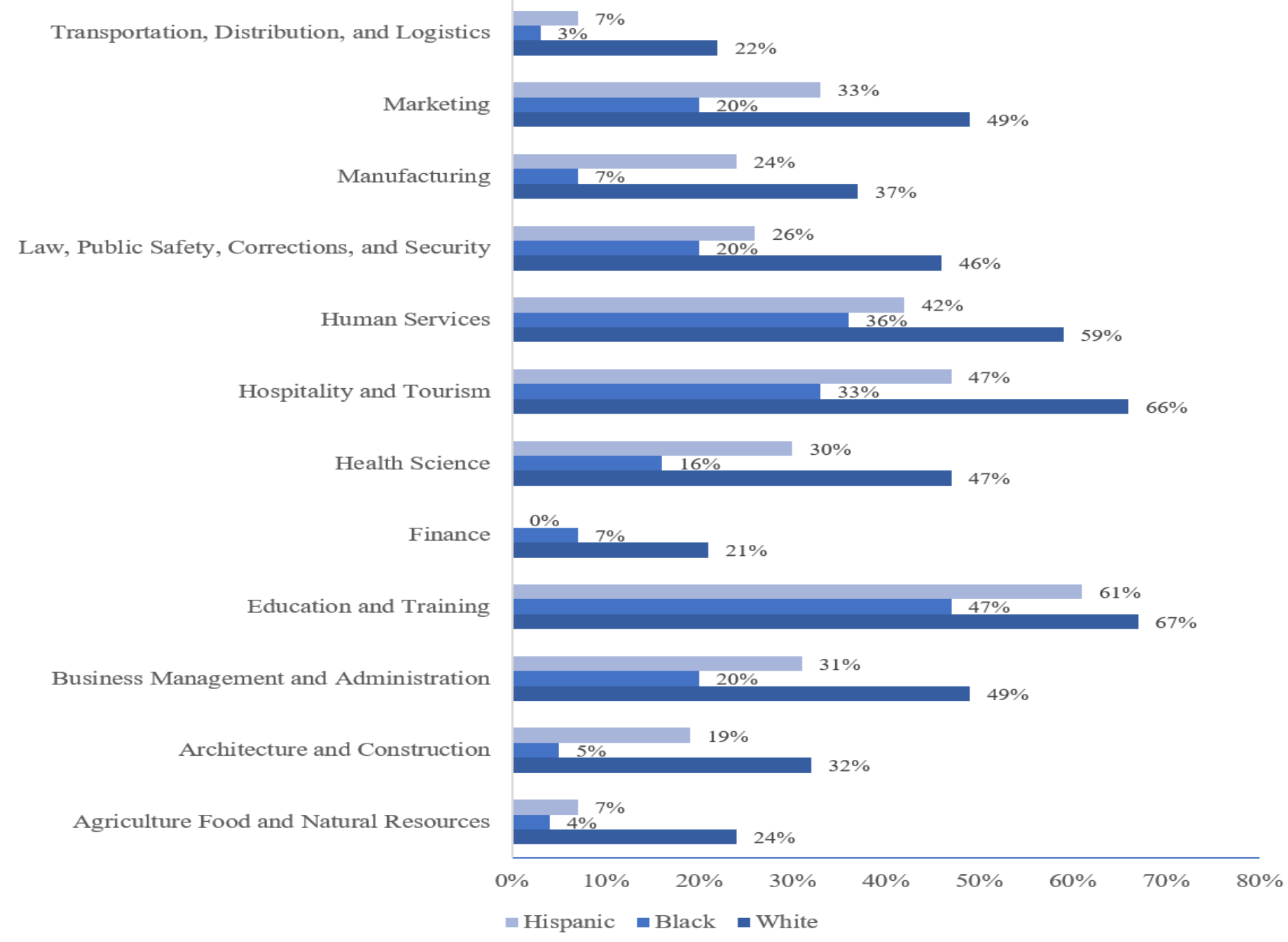

Source: MS-CPAS Assessment Data, 2015-2021

\section{Discussion}

In this study, we explored the enrollment patterns of Mississippi secondary CTE students by career cluster, as well as by career pathways that are associated with STEM careers over the last five years. Enrollment patterns were also compared to statewide enrollment patterns by gender and ethnicity. In STEM-related career clusters, female student enrollment was larger than male participation $(42.39 \%$ male, $57.61 \%$ female), due to the pronounced gender disparity in the Health Science career cluster ( $13.50 \%$ male, $86.50 \%$ female). Student enrollment in non-STEM-related CTE clusters was the reverse over the last five years ( $52.97 \%$ male, $47.03 \%$ female), but was closer to the state's enrollment by gender. Regarding ethnicity, all nontraditional student groups were underrepresented in STEM-related CTE programming (40.4\% African American, 55.3\% White), whereas African American students were enrolled at more equitable rates than their White counterparts in none-STEM career clusters $(47.0 \%$ African American, 49.4\% White).
These secondary CTE student enrollment results somewhat mimic the patterns of underrepresentation of nontraditional students in STEM-related career fields (National Science Foundation, 2019); however, the enrollment patterns for most STEM career pathways are above $25 \%$, which is the threshold for Perkins V non-traditional program concentration core indicator of performance for 4S1 (United States Department of Education, 2021). These results suggest that the CTE and non-CTE leaders in the state and school districts have been more effective in recruiting females and minority students to enroll in STEM-related career pathways. More work is needed in this area to ensure that this high-demand, high-wage career pathways are accessible to all students (Burbank et al., 2021).

As we explored the proficiency results of students on the statewide CTE assessments, we found similar outcomes as in the enrollment patterns. Males scored higher than females regardless of whether or not the career pathway was a STEMrelated pathway. The Business Management and Administration 


\author{
E-ISSN: 2469-6501 \\ VOL: 7, ISSUE: 11 \\ November/202 1 \\ DOI: http://dx.doi.org/10.33642/ijbass.v7n11p5

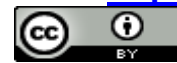 \\ https://creativecommons.org/licenses/by/4.0/
}

career cluster was the only outlier of this result. This disparity between students scoring proficient or higher was even more marked when disaggregating by ethnicity $(M=28.17 \%)$ in STEM-related CTE pathways. Unfortunately, these results also mimic the patterns of proficiency female and minority students earned on science statewide and national examinations over the past five years.

\section{CONCLUSION}

This study was unique because it explored the impact that career technical education may have on nontraditional students' enrollment in STEM-related coursework during high school (Dalton et al., 2013; Fletcher, 2012) and their performance on statewide STEM assessments (Plasman et al., 2020; Usher et al., 2019). As discussed in other studies, there is a gap in the research related to CTE in general. Likewise, more research is needed when exploring equitable access in CTE as school systems try to align more closely to workforce demands in the 21st century (Dougherty, 2016; Kim et al., 2021). This study supports the findings of Byars-Winston et al. (2015), Alonso-Villar \& del Río (2017), and Leu and Arbeit (2020) that school systems are not building a robust enough pipeline for female and minority students in STEM-related careers based on current state enrollment patterns. However, in Mississippi, it is promising to see that there is less disparity in nontraditional student enrollment in STEM-related career pathways than on the national scale in high school coursework or labor market patterns (Plasman et al., 2020; United States Bureau of Labor Statistics, 2019). The results of the study also show that the disparity in student performance on statewide, science-based assessments still exists, indicating that more preparation is needed in this area for these subgroups of students (Gottfried et al., 2016; National Alliance for Partnerships in Equity, 2018). States should work toward tightening the connection between academic coursework and CTE coursework to promote more student achievement. One vehicle that has proven effective in recent years is the use of career academies, which integrate CTE coursework and academic coursework while tracking students' paths to labor market outcomes (Lanford \& Maruco, 2019; Plasman et al., 2020).

Since this study focused on high school students solely from CTE programs in Mississippi, caution should be taken when inferring that these results generalize to other states. Based on the results of this study, it does seem reasonable to assume that implementing core performance indicators like 4S1 in the Perkins V Act promotes more equitable student enrollment. States should consider implementing similar measures connected to school systems' accountability, which has been shown that this has been an effective mechanism for progressive educational change (Estes \& McCain, 2019; Estrada et al., 2016). As suggested earlier, more research is needed in this area from not only a qualitative approach but also a student-centered approach to further explore why certain demographics may or may not enroll in STEM-related coursework. School systems and society are finally in visible agreement concerning the desire to equip the future workforce for high-skill, high-demand jobs (Burbank et al., 2021; Kell et al., 2020). It is up to CTE practitioners and researchers alike to help policymakers discover the most effective mechanisms for all.

\section{Acknowledgment}

We would like to thank Bhanu Shanmugam for providing the assessment data for the study and we would also like to thank Heather Craig for editing the paper. We would also like to thank the MDE for their support and partnership in research.

\title{
References
}

Advance CTE. (2021). Career clusters. Retrieved from https://careertech.org/career-clusters

Advance CTE. (2019). Making Good on the Promise: Building Trust to Promote Equity in CTE. https://careertech.org/resource/building-trust-promote-equity-cte

Advance CTE. (2018). Making Good on the Promise: Understanding the Equity Challenge in CTE. https://careertech.org/resource/understanding-equity-challenge-cte

AIR. (2021). Building the U.S. Workforce of the Future: Key Challenges and Opportunities. American Institute for Research. https://www.air.org/resource/field/building-us-workforce-future-key-challenges-and-opportunities

Alonso-Villar, O., del Río, C., \& Gradin, C. (2012). The extent of occupational segregation in the United States: Differences by race, ethnicity, and gender. Industrial Relations: A Journal of Economy and Society, 51(2), 179-212. https://doi.org/10.1111/j.1468-232X.2012.00674.X

Bandura, A. (1986). Social foundations of thought and action: A social cognitive theory. Englewood Cliffs, N.J: Prentice-Hall.

Blau, F.D., Brummond, P., \& Yung-Hsu Liu, A. (2013). Trends in occupational segregation by gender 1970-2009: Adjusting for the impact of changes in the occupational coding system. Demography, 50, 471-492. https://doi.org/10.1007/s13524-012-0151-7

Burbank, C., Romanillos, R., \& Williams, B. (2021). Equity in CTE \& STEM root causes and strategies: A call to action. PA: NAPE Education Foundation, Inc. 


\author{
E-ISSN: 2469-6501 \\ VOL: 7, ISSUE: 11 \\ November/202 1 \\ DOI: http://dx.doi.org/10.33642/ijbass.v7n11p5 \\ (c) (7) \\ https://creativecommons.org/licenses/by/4.0/
}

Byars-Winston, A., Fouad, N., \& Wen, Y. (2015). Race/ethnicity and sex in U.S. occupations, 1970-2010: Implications for research, practice, and policy. Journal of Vocational Behavior, 87, 54-70. https://doi.org/10.1016/j.jvb.201

Carl D. Perkins Career and Technical Education Act of 2006, 20 U.S.C. § 2301 et seq. (2006).

Carnevale, A. P., Smith, N., \& Strohl, J. (2013). Recovery: Job growth and education requirements through 2020. Center on Education and the Workforce.

https://cew.georgetown.edu/cew-reports/recovery-job-growth-and-education-requirements-through-2020/

Chavatzia, T. (2017). Cracking the code: Girls' and women's education in science, technology, engineering and mathematics (STEM). United Nations Educational, Scientific, and Cultural Organization.

https://unesdoc.unesco.org/ark:/48223/pf0000253479

Cook-Harvey, C. M., Darling-Hammond, L., Lam, L., Mercer, C., \& Roc, M. (2016). Equity and ESSA: Leveraging educational opportunity through the Every Student Succeeds Act. Learning Policy Institute.

https://learningpolicyinstitute.org/product/equity-essa-report

Curnow, C., \& Calderon, R. (2021). Supporting labor market resiliency and future-readiness:

The case for measuring skill demand in real time. American Institute for Research.

https://www.air.org/sites/default/files/Supporting-Labor-Market-Resiliency-Future-Skills-Brief-WDEMP-April-2021.pdf

Dalton, B., Lauff, E., Henke, R., Alt, M., \& Li, X. (2013). From track to field: Trends in career and technical education across three decades. Washington, DC: U.S. Department of Education

DeFalco, A. (2016). Dewey and vocational education: still timely? The Journal of School and Society, 3(1), 54-64.

Dougherty, S. M. (2016). Career and technical education in high school: Does it improve student outcomes? Thomas B. Fordham Institute. https://fordhaminstitute.org/national/research/career-and-technical-education-high-school-does-itimprove-student-outcomes

Duff, M., \& Wohlstetter, P. (2019). Negotiating Intergovernmental Relations Under ESSA.

Educational Researcher, 48(5), 296-308.

https://doi.org/10.3102/0013189x19854365

Estes, A., \& McCain, B. (2019). Four strategies to address equity in CTE. State Education Standard, 19(3), 10.

Estrada, M., Burnett, M., Campbell, A. G., Campbell, P. B., Denetclaw, W. F., Gutiérrez, C. G., ... \& Zavala, M. (2016). Improving underrepresented minority student persistence in STEM. CBE_Life Sciences Education, 15(3), es5. https://doi.org/10.1187/cbe.16-01-0038

Every Student Succeeds Act, 20 U.S.C. § 6301 (2015). https://www.congress.gov/114/plaws/pub195/PLAW-114pub195.pdf

Fletcher, J. (2012). Predicting the influence of demographic differences and schooling experience in adolescence on occupational choice in adulthood. Career and Technical Education Research, 37(2), 121-139.

Fletcher Jr, E., \& Zirkle, C. (2009). The relationship of high school curriculum tracks to degree attainment and occupational earnings. Career and Technical Education Research, 34(2), 81-102.

Gottfried, M. A., Bozick, R., Rose, E., \& Moore, R. (2016). Does career and technical education strengthen the STEM pipeline? Comparing students with and without disabilities. Journal of Disability Policy Studies, 26(4), 232-244.

https://doi.org/10.1177/1044207314544369

Hackmann, D.G., Malin, J.R., \& Gilley, D. (2018). Career academies: Effective structures to promote college and career readiness, The Clearing House: A Journal of Educational Strategies, Issues and Ideas, 91(4-5), 180-85.

https://doi.org/10.1080/00098655.2018.1480196

Hamilton, A. F., Malin, J., \& Hackmann, D. (2015). Racial/Ethnic and gender equity patterns in Illinois high school career and technical education coursework. Journal of Career and Technical Education, 30(1), 29-52.

Hess, F. M. (2010). The same thing over and over: How school reformers get stuck in yesterday's ideas. Cambridge, MA: Harvard University Press.

IBM Corp. (2021). IBM SPSS Statistics for Windows, Version 28.0. Armonk, New York. 


\author{
E-ISSN: 2469-6501 \\ VOL: 7, ISSUE: 11 \\ November/202 1 \\ DOI: http://dx.doi.org/10.33642/ijbass.v7n11p5 \\ (c) (†) \\ https://creativecommons.org/licenses/by/4.0/
}

Jurado de los Santos, P., Moreno-Guerrero, A. J., Marín-Marín, J. A., \& Soler Costa, R. (2020). The term equity in education: A literature review with scientific mapping in Web of science. International Journal of Environmental Research and Public Health, 17(10), 3526.

Kell, H. J., Roohr, K. C., \& Fishtein, D. (2020). Who's who in CTE occupations: Documenting the demographic composition of CTE job holders. Research notes. Career and Technical Education Series. Educational Testing Service.

Kim, E. H., Flack, C. B., Parham, K., \& Wohlstetter, P. (2021). Equity in secondary career and technical education in the United States: A theoretical framework and systematic literature review. Review of Educational Research, 91(3), 356-396.

Landers, P. (2019). Ensuring Equity in Evolving High School Career and Technical Education Policies. Institute for Research on Poverty.

https://www.irp.wisc.edu/resource/ensuring-equity-in-evolving-high-school-career-and-technical-education-policies/

Lanford, M., \& Maruco, T. (2019). Six conditions for successful career academies. Phi Delta Kappan, 100(5), 50-52. https://doi.org/10.1177/0031721719827547

Leedy, P. D., \& Ormrod, J. E. (2019). Practical research: Planning and design (12 ${ }^{\text {th }}$ ed.). Pearson.

Lent, R. W., \& Brown, S. D. (2019). Social cognitive career theory at 25: Empirical status of the interest, choice, and performance models. Journal of Vocational Behavior, 115, 103316.

Lent, R. W., Brown, S. D., \& Hackett, G. (1994). Toward a unifying social cognitive theory of career and academic interest, choice, and performance. Journal of vocational behavior, 45(1), 79-122.

Leu, K. B., \& Arbeit, C. A. (2020). Differences in high school CTE course taking by gender and race/ethnicity. Career and Technical Education Research, 45(1), 33-62.

Mississippi Department of Education. (2021, August 1). Data Downloads. Retrieved from https://newreports.mdek12.org/DataDownload

National Alliance for Partnerships in Equity (2018). Equity gap analysis - State. Gap, PA. Retrieved from https://www.napequity.org/nape-content/uploads/NAPE-Perkins-V-Equity-GapAnalysis-At-A-Glance_v3_10-16$18 \mathrm{ml}$.pdf

National Center for Education Statistics (NCES). (2017). Science Performance. Retrieved from https://nces.ed.gov/programs/coe/indicator/cne

National Science Foundation. (2018). ADVANCE: Increasing the participation and advancement of women in academic science and engineering careers. Retrieved from https://www.nsf.gov/funding/pgm_summ.jsp?pims_id=5383

No Child Left Behind Act of 2001, 20 U.S.C. $§ 6301$ (2002).

https://www.congress.gov/107/plaws/publ110/PLAW-107publ110.pdf

OECD. (2021). OECD Statistics. Retrieved from https://stats.oecd.org/

Perry, A. (2019). Making the Most of Perkins V. National Association of State Boards of Education. https://files.eric.ed.gov/fulltext/EJ1229625.pdf

Plasman, J. S., Gottfried, M. A., \& Klasik, D. (2020). Trending up: A cross-cohort exploration of STEM career and technical education participation by low-income students. Journal of Education for Students Placed at Risk (JESPAR), 25(1), 55-78.

Rosen, R., \& Molina, F. (2019). Practitioner Perspectives on Equity in Career and Technical Education. MDRC. https://www.mdrc.org/publication/practitioner-perspectives-equity-career-and-technical-education

Shankar-Brown, R. (2015). Urbanization and persistent educational inequalities: The need for collective action towards equity and social justice. National Youth-At-Risk Journal, 1(1), 31.

United States Bureau of Labor Statistics. (2019). Labor force characteristics by race and ethnicity, 2019. Retrieved from https://www.bls.gov/opub/reports/race-and-ethnicity/2019/home.htm

U.S. Department of Education, Office of Career, Technical, and Adult Education. (2021). Consolidated Annual Report (CAR). Adapted from https://cte.ed.gov/dataexplorer/build_enrollment.

Usher, E., Ford, C., Li, C., \& Weidner, B. (2019). Sources of math and science self-efficacy in rural Appalachia: A convergent mixed methods study. Contemporary

Educational Psychology, 57, 32-53. https://doi.org/10.1016/j.cedpsych.2018.10.003 